Prima: Jurnal Pendidikan Matematika

Vol. 6, No. 1, January 2022, pp. 30-39

P-ISSN: 2579-9827, E-ISSN: 2580-2216

Web: http://jurnal.umt.ac.id/index.php/prima

\title{
MONTESSORI MATHEMATICS FOR STUDENTS WITH PERVASIVE DEVELOPMENTAL DISORDER - NOT OTHERWISE SPECIFIED
}

\author{
Dyah Ayu Sulistyaning Cipta ${ }^{1}$, Era Dewi Kartika², Anik Kurniawati ${ }^{3}$ \\ IKIP Budi Utomo,Jl. Simpang Arjuno No 14B, Kauman, Kec Klojen, Malang, Jawa Timur, Indonesia. \\ e-mail: erfolgera@gmail.com
}

\begin{abstract}
Montessori is a learning method that uses the surrounding environment as a learning resource. This research is aimed at describing how the Montessori method is applied to Mathematics for students who survive Pervasive Developmental Disorder - Not Otherwise Specified (PDD-NOS). The research method used is descriptive qualitative. The research subjects were PDD-NOS grade V SD students in inclusive schools. The research instruments were documentation, observation, and interviews. The results showed that students with PDD-NOS who have delays in communication can more easily accept mathematics learning using the Montessori method. This is supported by the Montessori concept which allows PDD-NOS students to use lego in learning fractions.
\end{abstract}

Keywords: montessori, mathematics, fraction, PDD-NOS, autism

\begin{abstract}
Abstrak
Montessori merupakan suatu metode pembelajaran yang sumber belajarnya menggunakan lingkungan sekitar. Tujuan dari penelitrian ini adalah mendeskripsikan bagaimana metode Montessori diterapkan pada siswa dengan PDD-NOS atau Pervasive Developmental Disorder - Not Other Specified pada matematika di kelas. Deskriptif kualitatif merupakan metode yang digunakan dalam penelitian. Subjek penelitian adalah siswa kelas V SD yang mengalami PDD-NOS di sekolah inklusi. Instrumen penelitian adalah dokumentasi, observasi, dan wawancara. Pada penelitian diperoleh hasil bahwa siswa dengan PDD-NOS yang mengalami keterlambatan komunikasi dapat lebih mudah menerima pembelajaran matematika dengan menggunakan metode Montessori. Hal ini didukung dengan konsep Montessori yang memungkinkan siswa PDD-NOS menggunakan lego dalam pembelajaran pecahan. Materi pecahan yang diterapkan pada penelitian ini adalah penjumlahan dan pengurangan pecahan.
\end{abstract}

Kata kunci: Montessori, matematika, pecahan, PDD-NOS, autisme

\section{INTRODUCTION}

Montessori is a learning method by Maria Montessori. She is a doctor who is devoted to making learning houses for mental disorders children. Concept of Montessori in learning activities is different from other concepts. Montessori offers independence, freedom, flexibility of space and time, and fosters student creativity (Fleming, et al, 2019). The principle of independence in the Montessori method teaches about life skills according to their developmental stage (Wulandari, et al, 2018).

The Montessori method provides the principle of freedom, presenting learning activities according to what is being experienced and needed by students in their time with the surrounding environment as a learning resource. Montessori takes everything from the environment and manifests it in the child. It frees children to choose for themselves what 
they will learn. The prepared Montessori learning environment can be physical or psychological (Mumtazah and Rohmah, 2018).

Flexibility in space and time in the Montessori method means allowing children to choose whether to study in the classroom or outside. With a fun learning process, the classroom can be used as a stage for playing and children can choose what they will do. Although both are fun, the concept of the Montessori method is different from Playful Learning. Fun activities in Montessori are work activities to realize an understanding, while fun activities in Playful Learning are game activities that have been arranged in such a way as a play (Lillard, 2013).

Montessori with learning that refers to the environment, can shape children into creative individuals. Children can freely learn without being constrained by standard rules. Montressori avoids giving extrinsic rewards, reduces emphasis on academic testing, and eliminates competition between students (Marshall, 2017). Everyone is a star.

The Montessori principle that makes every student a star without competition with other students is very suitable to be applied to inclusive schools, schools that invite students with special needs to participate in learning with other students in general. Three classifications of students with special needs based on the type of disability are physical disability, mental disability, and intellectual disability. One type of mental disability is students with Autism Spectrum Disorder (ASD).

Kose, et al (2017) stated that ASD is classified into several types, including Classic Autism, Asperger's Syndrome, Childhood Disintegrative Disorder, and Persuasive Developmental Disorder - Not Otherwise Specified (PDD-NOS). PDD-NOS has heterogeneous characteristics (Hassan and Perry, 2011), it cannot be easily enforced through the Diagnostic and Statistical Manual of Mental Disorders (DSM) checklist. Mandy, et al (2011) stated that a person is said to be a PDD NOS survivor if he or she has some, but not all, characteristics of ASD. He is in the ASD category, but not Classic Autistic, not Asperger's, nor is Childhood Disintegrative Disorder. The diagnosis of PDD-NOS is given to children who show impairments in social interaction skills, difficult on communication, or the presence of repetitive/stereotypical behaviors (Brennan, et al, 2015).

Although ASD is in the category of special needs with mental disabilities, $60 \%$ of ASD cases are accompanied by intellectual disabilities. However, according to Brentani, et al 
(2013) children with PDD-NOS and Asperger's Syndrome have normal intellectual intelligence. However, PDD-NOS's mental disability made him unable to attend regular schools. The student must study at an Extraordinary School or an Inclusive School with the provision of a special assistant teacher. The existence of a special assistant teacher is very necessary because PDD-NOS students have difficulties in communicating. Compared to other types of PDD, according to Karabekiroglu (2011), PDD-NOS has very poor communication skills.

The Covid-19 pandemic that has hit the country since March 2020 has made the government take a policy to enforce school from home. While students are at home, teachers will carry out learning activities at school using an online system. Through various media, it is hoped that learning will continue to run well, even though students and teachers cannot meet face to face. Likewise with SDI Mohammad Hatta.

SDI Mohammad Hatta is an inclusive school that has PDD-NOS students. According to the special assistant teacher at the school, the learning implemented during the pandemic was completely ineffective for students with special needs, especially ASD students. ASD students who have problems in social interaction and communication require special treatment to attract their attention so that they can focus on the learning that is taking place. At SDI Mohammad Hatta, online learning is carried out using media zoom meetings, video calls, and audiovisual multimedia.

Zoom meetings are held once a week with class teacher participants and all students in the class. Video calls are made every day in rotation with the class teacher and seven students. The purpose of holding video calls is so that students and teachers can interact more optimally. While audiovisual multimedia is given every day with assessments that are also carried out every day. Because PDD-NOS students cannot carry out learning activities without assistance, in this online learning, they are accompanied by a special assistant teacher at home.

Still according to the special assistant teacher at SDI Mohammad Hatta, online learning with direct assistance is still not optimal for the development of PDD-NOS students. These students are very difficult to focus on audiovisual multimedia as well as on learning activities with zoom meetings and video calls. Focusing attention is very difficult. So, we need a learning method that can replace the direct interaction of students that should be 
obtained in online learning. Referring to Cipta, et al (2019) that the Montessori method makes ASD students more expressive, able to express their will, and communicate well, this research will discuss how the Montessori method is applied to PDD NOS students in Mathematics.

\section{METHODS}

Montessori Mathematics Research on PDD-NOS or Pervasive Developmental Disorder - Not Otherwise Specified students was conducted with qualitative descriptive. The research subjects were PDD-NOS students at SDI Mohammad Hatta. The diagnosis of PDD-NOS is based on school documentation carried out by a child development specialist.

The Montessori method was applied in class $V$ on Fractions for all students in the class, but the focus of the research was only on PDD-NOS students. Research is conducted in a network. The researcher is with the teacher at school, while the PDD-NOS students are at home with the special assistant teacher. The research was conducted in the odd semester 2020/2021 with six online meetings.

The research instruments used in the study were documentation, observation, and interviews with PDD-NOS students. The research instrument has been validated by two validators, namely professionals in mathematics education and professionals in special education.

\section{RESULTS AND DISCUSSION}

The student who survived Pervasive Developmental Disorder-Not Otherwise Specified was the focus of the research had an IQ of 96 . The data were obtained from documents owned by SDI Mohammad Hatta. Her intellectual intelligence is normal, in the lower average range. Mordre, et al (2012) stated that the prognosis of PDD-NOS survivors is largely determined by their intellectual intelligence. Based on this, PDD-NOS students who are the focus of this study have a good prognosis.

She experiences the characteristics of active but strange social interactions. She will spontaneously approach other students, but this interaction is often inappropriate and often one-sided. In communicating, she often talks to himself and repeats snippets of words or songs and pronounces them in front of others in an inappropriate atmosphere. She also has trouble concentrating, as well as impulsivity. 
At the first meeting, the researcher participated when PDD-NOS students did learning by video calling with the class teacher. However, the presence of researchers made PDDNOS students uncomfortable. She fixed his eyes on the researcher with a sharp glare and his brows furrowed. It did not stop there, according to the special assistant teacher, the student then slammed her cellphone and did not continue learning activities. Jauhari (2016) states that this characteristic is a sign that students are reluctant to meet new people. She felt disturbed by the presence of new people around her. In order for the research to run smoothly as it should, in the next activity the researcher does not show her face in the video call.

The material given in the study was the addition and subtraction of common and mixed fractions. The lesson begins by inviting PDD-NOS students to choose food for breakfast. The food provided consists of various types of bread. Students choose a loaf of bread in the shape of a circle. By using sweetened condensed milk poured on white bread, PDD-NOS students will hone their fine motor skills. After the bread is ready to be eaten, the special assistant teacher, following the learning guidelines that have been prepared by the researcher and class teacher, will cut the bread into several pieces while mentioning the fractional value. Through the Three Period Lesson concept in the Montessori method, students will recognize fractions through three stages, namely naming, recognizing, and remembering. Jackson, et al (2011) in their research stated that five of the six subjects studied were quicker to recognize an object definition through Montessori learning with the Three Period Lesson concept than the introduction of direct instruction.

It doesn't just stop at bread, the introduction of fractions is continued by freeing students to define fractions using the surrounding environment according to what they want. PDD-NOS students who really like lego, choose it as a learning tool to recognize fractions.

At the second meeting, using lego, PDD-NOS students will learn about equivalent fractions as shown in Figure 1 below. 


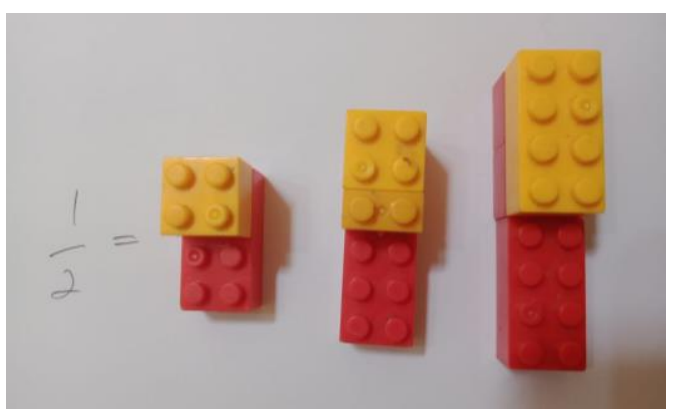

FIGURE 1. Equivalent fractions illustrated using lego

There is no significant problem in introducing equivalent fractions to PDD-NOS students. His interest in playing lego makes learning these fractions enjoyable. He didn't heed the offer of the inclusion assistant teacher to use other objects in the environment to learn fractions. Jacques, et al (2018) stated that when Autism Spectrum Disorder (ASD) is interested in an item or game, then he will continue to use the item or play the game. It will do it over and over again and it's hard to get distracted and focused on something else. In accordance with the Montessori rule which frees students to choose their learning sources, learning Fractions for PDD-NOS students remains only by using Lego.

After students have understood about equivalent fractions, then the next meeting is about the addition of two ordinary fractions. By using lego in the Montessori method, adding fractions can use the steps as shown in Figure 2 below.

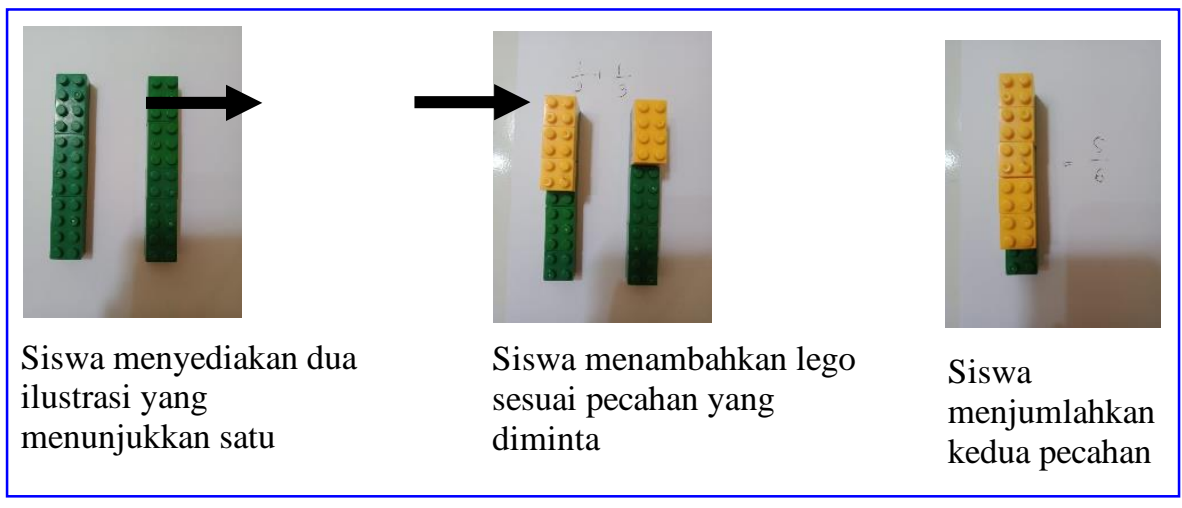

FIGURE 2. Using lego to calculate $\frac{1}{2}+\frac{1}{3}$

Using lego, students can learn to add two fractions quickly. There are no significant difficulties encountered in adding two fractions. The difficulty was found precisely when PDD-NOS students were directed to formulate that $\frac{a}{b}+\frac{c}{d}=\frac{\mathrm{ad}+\mathrm{cb}}{\mathrm{bd}}$. However, without referring to the formulation, PDD-NOS students have been able to add up two fractions. The special 
accompanying teacher suspected that the PDD-NOS students only had difficulty conveying conclusions, when in fact they had understood the essence of the material. This is based on the problem of communication difficulties he experienced.

Fraction subtraction can be illustrated as follows. For example, in subtraction $\frac{3}{4}-\frac{2}{5}$. Fraction of $\frac{3}{4}$ if illustrated using lego:

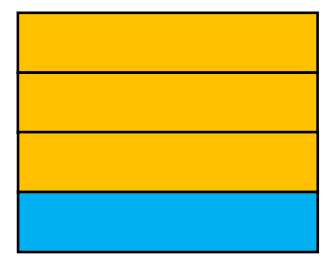

or

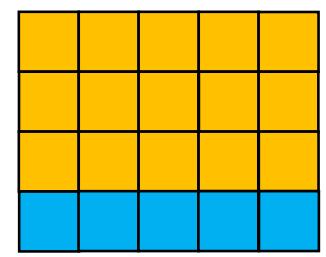

While the fraction $\frac{2}{5}$ if illustrated using lego

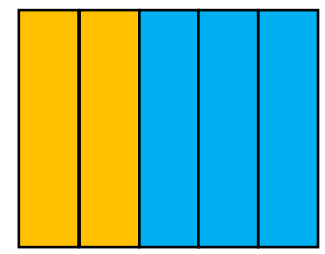

or

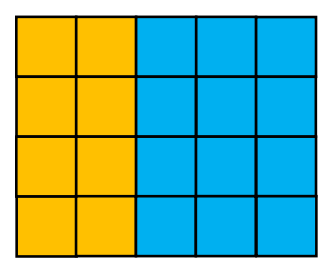

So if the illustration is $\frac{3}{4}$ minus the illustration $\frac{2}{5}$, then the lego shape becomes

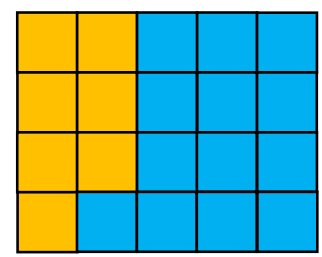

The Lego is worth the fraction $\frac{7}{20}$. Do it over and over again using other fractional numbers so that you find a pattern $\frac{a}{b}-\frac{c}{d}=\frac{\mathrm{ad}-\mathrm{cb}}{\mathrm{bd}}$.

By using a similar method, the subtraction of two fractions can be done easily by PDD-NOS students. At the fifth meeting, there was a tantrum because PDD-NOS students had difficulty removing the lego that was too attached. Tantrums are excessive emotions due to unpleasant conditions that the child feels as a result of unfulfilled desires or the child is unable to express these desires. Sulistyo (2017) states that tantrums are often carried out by autistic children, and tantrums can be shown by hitting, kicking, crying, biting, and 
screaming. When a tantrum occurs, learning is temporarily stopped and replaced at the next meeting.

Several things that the researcher found in learning fractions using the Montessori method were the better expressive attitude of the PDD-NOS students. He is more daring to show his pocket sense and not to something. His verbal communication can be trained well when he and the teacher play lego in counting fractions. While the drawback is that the teacher takes a long time to shift his focus from Lego to other things that become subjects after Mathematics.

\section{CONCLUSION}

The Montessori method, which gives students the freedom to choose their own learning resources, makes Mathematics feel close and truly experienced by students. Montessori is considered suitable for survivors of Pervasive Developmental Disorder - Not Otherwise Specified because its application is adapted to their learning abilities. PDD-NOS students who have delays in communication, can more easily accept learning that is experienced. He can understand quickly when learning is presented according to his interests.

\section{REFERENCES}

Brennan, L., M. Barton, C. M. Chen, J. Green, D. Fein. (2015). Detecting Subgroups in Children Diagnosed with Pervasive Developmental Disorder - Not Otherwise Specified. J Autism Dev Disord, 45 (5), 1329-1344. doi: 10.1007/s10803-014-2295-3

Brentani, H., C. S. Paula, D. Bordini, D. Rolim, F. Sato, J. Portolese, M. C. Pacifico, J. T. McCracken. (2013). Autism Spectrum Disorders: An Overview on Diagnosis and Treatment. Revista Brasileira de Psiquiatria, 35 (1), $62 \quad$ - 72. https://doi.org/10.1590/1516-4446-2013-S104

Cipta, D. A. S., D. Avianty, A. Kurniawati. (2019). Profil Berpikir Kritis Siswa Asperger pada Pembelajaran Bangun Datar dengan Metode Montessori. Jurnal Didaktik Matematika, 6 (2), 149 - 160. https://doi.org/10.24815/jdm.v6i2.14175 
Fleming, D.J., B. Culclasure, D. Zhang. (2019). The Montessori Model and Creativity. Journal of Montessori Research, 5 (2), 1 - 14. https://doi.org/10.17161/jomr.v5i2.7695

Hassan, N. dan Perry, A. (2011). Exploring the Characteristics of Children with a Diagnosis of PDD-NOS. Journal on Defelopmental Disabilities, 17 (1): 68 - 71.

Jackson, Rebbeca L. W. (2011). The Montessori Method's Use of Seguin's Three-Period Lesson and Its Impact on the Book Choices and Word Learning of Students Who Are Deaf or Hard of Hearing. Columbia University Libraries. https://doi.org/10.7916/D81N8735.

Jacques, C., V. Courchesne, A. S. Meilleur, S. Mineau, S. Ferguson, D. Cousineau, A. Labbe, M. Dawson, L. Mottron. (2018). What Interests Young Autistic Children? An Exploratory Study Of Object Exploration And Repetitive Behavior. PLOS ONE, 13(12): e0209251. https://doi.org/10.1371/journal.pone.0209251

Jauhari, M. N. (2016). Identifikasi Perkembangan Komunikasi Anak Pervasive Developmental Disorder. Helper: Jurnal Bimbingan dan Konseling, 32 (2), 1 - 11.

Karabekiroglu, K. (2011). “Pervasive Developmental Disorder-not Otherwise Specifified: Specifying and Differentiating." Autism Spectrum Disorders: The Role of Genetics in Diagnosis and Treatment. London, SW7 2QJ. doi: 10.5772/18618

Kose, Z., F. T. Ocakoglu, B. K., Ocakoglu, B. Ozbaran. (2017). The Naturalistic Follow-Up Of Pervasive Developmental Disorders-Not Otherwise Specified Cases. Psychiatry and $\begin{array}{llllll}\text { Clinical Psychopharmacology, } & 27 & (3), & 243 & - & 248 .\end{array}$ https://doi.org/10.1080/24750573.2017.1342754

Lillard, A. S. (2013). Playful learning and Montessori education. American Journal of Play, 5(2), 157-186.

Marshall, C. (2017). Montessori Education: A Review of the Evidence Base. NPJ Science Learn 2, 11. https://doi.org/10.1038/s41539-017-0012-7

Mumtazah, D., L. Rohmah. (2018). Implementasi Prinsip-prinsip Montessori dalam Pembelajaran AUD. GOLDEN AGE: Jurnal Ilmiah Tumbuh Kembang Anak Usia Dini, 3 (2), 91 - 102. https://doi.org/10.14421/jga.2018.91-102

Mandy W, Charman T, Gilmour J, Skuse D.(2011). Toward Specifying Pervasive Developmental Disorder-Not Otherwise Specified. Autism Research, 4 (2), 121 - 131. doi: $10.1002 /$ aur.178 
Mordre, M., B Groholt, A. K. Knudsen, E. Sponheim, A. Mykletun, A. M. Myhre. (2012). Is long-term prognosis for pervasive developmental disorder not otherwise specified different from prognosis for autistic disorder? Findings from a 30-year follow-up study. Journal of Autism and Developmental Disorders, 42 (6), 920-928. doi: 10.1007/s10803011-1319-5

Sulistyo, M., A. S. Choiri, F. Hidayatullah. (2017). Decreasing Tantrum Of Child With Autism Using Brain Gym. European Journal of Special Education Research, 2 (2), 62 - 71. http://dx.doi.org/10.5281/zenodo.242907

Wulandari, D. A., Saifuddin, J. A. Muzakki. (2018). Implementasi Pendekatan Metode Montessori dalam Membentuk Karakter Mandiri pada Anak Usia Dini. AWLADY: Jurnal Pendidikan Anak, 4 (2), 1 - 19. doi:10.24235/awlady.v4i2.3216 